\title{
Production and growth performance under carps polycuture with different stocking densities in hilly creeks of Kaptai lake, Rangamati
}

\begin{abstract}
An experiment was conduct to compare the performences of different carps i.e. rui (Labeo rohita), catla (Catla catla) and mrigal (Cirrhinus cirrhosus) in different stocking densities of polyculture. Three treatments each with three replicates were maintained and the stocking densities of carps were 80 (rui $30+$ catla $30+$ mrigal 20), $70(25+25+20)$ and $60(25+20+15)$ per decimal in T1, T2 and T3 respectively. Creeks were fertilized regularly; commercial feed was given for 300 days. The water quality parameter such as $\mathrm{pH}$, temparature dissolved Oxygen and transperency were observed fortnightly. The obtained results showed that the highest weight was gained at $622.50 \pm 293.50 \mathrm{~g}$ in treatments T3 by catla, followed by rui $(572.40 \pm 153.90 \mathrm{~g})$ and mrigal $(532.0 \pm 117.54 \mathrm{~g})$. However, lowest weight gain was in treatment $\mathrm{T} 1 \mathrm{for}$ all species. On the other hand, the highest SGR was found in treatment T3 for rui $(1.22 \pm 0.03)$ and the lowest SGR was in T1 for catla $(0.89 \pm 0.04)$. Furthermore, the highest production was obtained in treatment T1 $(468 \mathrm{~kg} / 0.1 \mathrm{ha} / 10$ months or $4623 \mathrm{~kg} /$ ha $/ 10$ months) followed by T2 $(452 \mathrm{~kg} / 0.1 \mathrm{ha} /$ months or $4465 \mathrm{~kg} / \mathrm{ha} / 10$ months $)$ and T3 ( $470 \mathrm{~kg} / 0.1 \mathrm{ha} /$ months or $4643 \mathrm{~kg} / \mathrm{ha} / 10$ months). Survival rate of T3 were highest for three species among the three treatments. The finding of this experiments revealed that, among three treatments, the stocking density of 60 fingerlings per decimal (T3) is the most suitable to ensure highest production on polyculture in creek.
\end{abstract}

Volume 2 Issue 4 - 2017

\author{
Sanjib Basak, Motiur Rahman, Abul Boshir, \\ Masud hossain Khan, Yahea Mahmud \\ Riverine Sub-Station (Lake Fisheries), Bangladesh Fisheries \\ Research Institute (BFRI), Bangladesh
}

\begin{abstract}
Correspondence: Motiur Rahman, Riverine Sub-Station (Lake Fisheries), Bangladesh Fisheries Research Institute (BFRI), Rangamati Hill District, Bangladesh, Email matiur.bfri@gmail.com
\end{abstract}

Received: June 04, 2017 | Published: June 23, 2017

Keywords: creeks, stocking density, polyculture, growth performances

\section{Introduction}

The area of the Chittagong Hill Tracts is about $13,2945 \mathrm{~km}^{2}$, which is approximately one-tenth of the total area of Bangladesh. Topographically, the Chittagong Hill Tracts are the hilly area in Bangladesh. The depression of hilly slope connected with the main Lake or its stream and become inundated with enormous hilly streams during monsoon is called the creek. Fish culture in creeks of the three hill districts has good prospects. Three sides of arms of the creek should be surrounded by hilly land while the rest remain directly linked with the main body of the Lake or not. A total number of 4727 creeks (covering 4297 ha areas) in Chittagong Hill Tracts (CHT) among them 1200 creeks are adjacent to the Kaptai Lake. ${ }^{1}$ The production capacity of these creeks is $2100 \mathrm{~kg} / \mathrm{ha}$ that is eight to nine times more than the Kaptai Lake. ${ }^{2}$ As a consequence of Bangladesh Fisheries Development corporation (BFDC) records, in the year 2002-03 total fish production of the Kaptai Lake was 4556 MT but it was 9364 MT in the year 2015-16. Over fifteen years, production of total fish from this Lake got attention but it is very noticeable that production of major carps (Labeo rohita, Catla catla, Cirrhinus cirrhosus) species decreased remarkably whereas small fishes especially (Gudusia chapra and Corica soborna) increased briskly. In spite of, the stocking of huge number of carp fingerling in the Lake per year but alarming decreases aforementioned species. According to Bashar, ${ }^{3}$ production from Lake is reported to have declined due to lack of optimum flow of water, siltation which reduces the rate of water flow and causes habitat degradation, the loss of spawning ground and decline of natural seed production of major carps fishes. Meanwhile, the current fish production at these Lake is going downwards and requires serious management effort through creek aquaculture in order to fully utilize the Lake's fishery potential.

The annual fish production of Chittagong Hill Tracts is 14773.46 MT (culture, capture and Kaptai Lake) which is comparatively less amount of total annual inland catch (FRSS, 2014). Our demand is increasing and cultivable land is decreasing for population explosion. To overcome these problems we have to take initiatives to produce more products by proper utilization of the limited resources. In this purpose, polyculture is the best culture system for maximum utilization of pond food web, ecosystem. ${ }^{4}$ The Department of Fisheries is trying to modernize creeks aquaculture activities in hill districts and conducted training programme for improvement of existing creeks by repairing and some steps were taken to create new creeks for fish culture. Bangladesh Fisheries Research Institute is trying to adopt fish culture technique and carrying out different research project on fish production improvement in the hilly creeks. The results of this study were helped to to popularize fish production technology in the creeks of Chittagong Hill District.

\section{Materials and methods}

\section{Study area and experimental design}

The experiment was carried out in a completely randomized design as given in Table 1. Fingerling were stocked at the rate of 80,70 and 60 fingerling per decimal. Fingerling size was $7-10 \mathrm{~cm}$. 


\section{Creeks selection and preparation}

Creeks was selected by examining creeks site, water retention capacity, and water depth (01 to $05 \mathrm{~m})$. Preparation of the creeks was done by repairing mouth of the creeks and unwanted sludge was removed from the creeks bottom. Lime was applied @ 250kg/ha. A concerned creeks was fertilized with compost (mixture of chopped and sun dried green plants $88 \%$, cow dung $10 \%$, urea $1 \%$ and lime $1 \%$ ) $1,250 \mathrm{~kg} / \mathrm{ha}$, urea @37.5kg/ha and TSP @25kg/ha).Then the creeks were left for 10 days to promote algal development.

\section{Collection and stocking of quality fry/Fingerling}

Good quality fingerlings was collected and required number of fingerlings was stocked in each creek after proper acclimatization.

\section{Feeding management and fertilization}

Formulated feed (25-28\% protein) was supplied twice daily @ 10 to $5 \%$ body weight of fish. The feed was adjusted periodically in accordance with the growth performance of fishes. Water of the creeks were fertilized monthly with urea @37kg/ha, TSP@25kg/ha and cow dung@1235kg/ha.

\section{Fish growth and water quality parameters monitoring}

At least $10 \%$ of each species of fishes was collected by seine net and growth was recorded fortnightly. Water quality parameters like air and water temperature, $\mathrm{DO}$, free $\mathrm{CO}_{2}$, total hardness, total alkalinity, $\mathrm{P}^{\mathrm{H}}$ was monitored fortnightly by using chemicals Kit Box. Transparency was measured by using secchi disc and water depth was measured manually by using meter scale.

\section{Final harvest and production estimation}

After 10 months of rearing, all fishes were harvested; growth and production was estimated.

\section{Economic analysis}

An economical analysis was performed to estimate the net return and benefit-cost ratio in different treatments. The following equation will be used: $\mathrm{R}=\mathrm{I}-(\mathrm{FC}+\mathrm{VC}+\mathrm{Ii})$ where, $\mathrm{R}=$ net return, $\mathrm{I}=$ income from sale, $\mathrm{FC}=$ fixed costs $\mathrm{VC}=$ variable costs and $\mathrm{Ii}=$ interest on inputs. Benefit cost ratio $(\mathrm{BCR})=$ Total net return/Total input cost .

\section{Data analysis and report writing}

For statistical analysis of data, a one-way ANOVA (Analysis of Variance) and DMRT (Duncan's Multiple Range Test) was done by using the SPSS (Statistical Package for Social Science) version-11.5. Significance was assigned at $1 \%$ level.

\section{Participatory approach at different stages of technology development}

A group of entrepreneurs living within the immediate vicinity of the creek, which have property right (beneficiaries), was assigned for overall management of the project. At least ten to fifteen beneficiaries was considered for a group selection including a team leader. Entrepreneurs was responsible for guarding, cleaning shoreline of creeks, administering feed as per requirement, taking part of fish harvesting, etc. By attending in all stages of technology development, they were capable to undertake such type of aquaculture system individually at the end of project period.

\section{Results and discussion}

\section{Water quality parameters}

Dissolved oxygen, $\mathrm{pH}$, water transparency and temperature were recorded monthly during the study period. The mean values of water quality parameters are presented in the Table 1 .The $\mathrm{P}^{\mathrm{H}}$ values of creeks water found to be fluctuated and ranged from 6.2 to 8.2. In treatment $\mathrm{T}_{1}, \mathrm{~T}_{2}$ and $\mathrm{T}_{3}$, the average $\mathrm{P}^{\mathrm{H}}$ of water were $7.3 \pm 0.45,7.3 \pm 0.94$ and $7.2 \pm 1.00$ respectively. Again, the Dissolved Oxygen concentrations of different creeks were ranged from 3 to 14 . The Dissolved oxygen concentrations under different treatments were found to be fluctuated around $6.12 \pm 1.13,6.27 \pm 0.66$ and $6.10 \pm 0.74$ in the treatments $\mathrm{T}_{1}, \mathrm{~T}_{2}$ and $\mathrm{T}_{3}$. Significant different $(\mathrm{p}>0.05)$ was not observed among the three treatments (Tables $1 \&$ Table 2).

Air temperature of creek water was found to be almost similar in different treatments without any significant difference. In $\mathrm{T}_{1}, \mathrm{~T}_{2}$ and $\mathrm{T}_{3}$ treatments it had figures of $26.26 \pm 3.8^{\circ} \mathrm{C}, 28.35 \pm 2.67^{\circ} \mathrm{C}$ and $28.93 \pm 3.58^{\circ} \mathrm{C}$ respectively. Water temperature was $27.24 \pm 4.26$, $26.03 \pm 6.47$ and $25.73 \pm 6.51$ in $\mathrm{T}_{1}, \mathrm{~T}_{2}$ and $\mathrm{T}_{3}$ respectively. The transparency of the treatments $\mathrm{T}_{1}, \mathrm{~T}_{2}$ and $\mathrm{T}_{3}$ were $1.35 \pm 0.35 \mathrm{~m}$, $1.82 \pm 1.19 \mathrm{~m}$ and $32.61 \pm 1.02 \mathrm{~m}$, respectively. Significant difference $(\mathrm{P}>0.05)$ was not observed between the treatments (Table 1). The transparency values in different treatments indicated that creek seemed to be within the productive range for fish culture.$^{3,5-7}$ Carbon-di-oxide $\left(\mathrm{CO}_{2}\right)$ of the treatments $\mathrm{T}_{1}, \mathrm{~T}_{2}$ and $\mathrm{T}_{3}$ were $3.52 \pm 1.6,4.02 \pm 1.33$ and $3.33 \pm 6.33$, respectively. Significant difference $(\mathrm{P}>0.05)$ was not observed between the treatments (Table 1). Total alkalinity and total hardness were significantly difference among the three treatments in Table 1.

\section{Growth performance of fish in different treatments weight gain}

It was observed that in treatment $T_{3}$ weight gain was higher compared to other treatments. However, significant differences were not observed among different fish species (Table 2). It might be due to the highest stocking density in treatment $\mathrm{T}_{1}$ and the lowest stocking density in treatment $T_{3}$. In the present study, the highest weight gain was found in catla $(622.50 \pm 293.50 \mathrm{~g})$ in $\mathrm{T}_{3}$ then rui and the lowest weight gained in mrigal $(493.60 \pm 112.36 \mathrm{~g})$ in $\mathrm{T}_{1}$. In contrary, Islam ${ }^{8}$ found the highest weight gain in rui $(231 \pm 0.87)$ in six month culture period. The specific growth rate (SGR) of rui was not significantly different among three treatments. However, SGR value of catla, rui and mrigal showed no significant difference $(\mathrm{p}<0.05)$ among the treatments (Table 3).The SGR value $2.28 \pm .05$ of rui in treatment $\mathrm{T}_{1}$ was higher compared to Milstein et al. ${ }^{9}$ who recorded SGR of rui ranged from 1.16 to 0.99 . The significant variation of SGR was found in mrigal, catla and silver carp. The highest SGR was found in silver carp in $\mathrm{T}_{1}(2.87 \pm 0.03)$ and the lowest SGR was found in catla in treatment $\mathrm{T}_{3}(1.51 \pm 0.06)$. Likewise, Modac (2006) found the SGR value of rui at $1.65 \pm 0.74$ in the Indian carp polyculture system which was almost similar result.

The total production was expressed in $\mathrm{kg} / \mathrm{ha} / 10$ monthly (Table 3). The combined production was the highest in treatment $T_{3}$ (470kg/0.1ha/10 months or $4643 \mathrm{~kg} / \mathrm{ha} / 10$ months) followed by treatment $\mathrm{T}_{1}(468 \mathrm{~kg} / 0.1 \mathrm{ha} / 10$ months or $4623 \mathrm{~kg} / \mathrm{ha} / 10$ months $)$ and treatment $\mathrm{T}_{2}(452 \mathrm{~kg} / 0.1 \mathrm{ha} / 10$ months or $4465 \mathrm{~kg} / \mathrm{ha} / 10 \mathrm{month})$. In this study, it was found that the production performance of each individual fish was not similar in the three treatments (Table 4). In general, the 
total fish production was the highest for all species in treatment $\mathrm{T}_{3}$ appropriate stocking density $(60 \mathrm{nos} / \mathrm{dec})$. On the contrary, in case of catla, the gross production was the highest in $T_{1}$ compared to $T_{2}$ and $\mathrm{T}_{3}$. The gross production of rui was the highest in $\mathrm{T}_{3}$ compared to $\mathrm{T}_{1}$ and $\mathrm{T}_{2}$. Moreover, mrigal, treatment $\mathrm{T}_{2}$ and $\mathrm{T}_{3}$ gave the almost same production but $\mathrm{T}_{1}$ gave lower production.

\section{Individual growth performance (g)}

Rui, catla, mrigal were stocked in three treatments at the rate of 80 $\left(\mathrm{T}_{1}\right), 70\left(\mathrm{~T}_{2}\right)$ and $60\left(\mathrm{~T}_{3}\right)$ fingerlings per decimal. The highest weight gain (Table 3) of rui $(572.40 \pm 153.90)$, catla $(622.50 \pm 293.50)$ and mrigal (532.50 118.32 ) was recorded in $\mathrm{T}_{3}$. Furthermore, the weight gains of rui. catla and mrigal were not significantly different among three treatments. Survival rate of $T_{3}$ were highest for three species among the three treatments. Survival rate of all treatment were all most 50 percent because fish feed were collected from other district. Creeks were situated very remote area and communication of creeks is not good. Sometime fish seed were carried to the creeks with aluminum pot from pick up for 2-3 hours. 10 hours were required for releasing fish seed from the time of collecting hatchery. Figure $1 \& 2$ shows the monthly growth performance of rui, catla and mrigal. In this experiment, the highest total production was found from treatment $\mathrm{T}_{3}(470 \mathrm{~kg} / 0.1 \mathrm{ha} / 10$ months or $4643 \mathrm{~kg} / \mathrm{ha} / 10$ months) followed by treatment $\mathrm{T}_{1}(468 \mathrm{~kg} / 0.1 \mathrm{ha} / 10$ months or $4623 \mathrm{~kg} / \mathrm{ha} / 10 \mathrm{month})$ and treatment $\mathrm{T}_{2}(452 \mathrm{~kg} / 0.1 \mathrm{ha} / 10$ months or $4465 \mathrm{~kg} / \mathrm{ha} / 10$ month), respectively. From polyculture system, the gross production was recorded $1,817 \mathrm{~kg} \mathrm{ha}^{-1}$ by Kohinur ${ }^{10}$ and $1,970 \mathrm{kgh}^{-1} \mathrm{Kadir}^{11}$ during five months of culture period and $2,560 \mathrm{~kg} \mathrm{ha}^{-1}$ by Roy ${ }^{12}$ during 7 months. The present study supported the finding of Sagor ${ }^{13}$ and Hossain. ${ }^{14}$ Our finding indicated that stocking density $60 \mathrm{nos} / \mathrm{dec}$ is most appropriate for polyculture. The net profit was calculated Tk. 86630.00, 83400.00 and 87280.00 in treatment 1,2 and 3, respectively per 0.1 ha creek per 10 months duration (Table 5) . Benefit-cost ratio (BCR) was obtained $1.35,1.27$ and 1.31 in $\mathrm{T}_{1}, \mathrm{~T}_{2}$ and $\mathrm{T}_{3}$ respectively. BCR was higher in treatment $T_{3}$ because the numbers of the three species were high other then two treatments $\left(\mathrm{T}_{2}, \mathrm{~T}_{3}\right)$. Similar finding was observed by NC Roy ${ }^{12}$ in their experiment. Among three treatments, only carps polyculture made Tk. 94, 925 net benefit per 7 months. BCR of this experiment was 3.94:1. From the overall discussion, it was found that successful polyculture of rui, catla and mrigal in creeks could be done with better production using the stocking density 60 fingerlings per decimal. ${ }^{15,16}$

Table I Experimental design of the project

\begin{tabular}{llll}
\hline Treatments & Stocking density (No./dec) & Species & Sizes (cm) \\
\hline $\mathrm{T}_{1}$ Rangamati Sadar & 80 & Rui (30), Catla (30), Mrigal (20) & $7-10$ \\
$\mathrm{~T}_{2}$ Naniachar & 70 & Rui (25), Catla (25), Mrigal (20) & $7-10$ \\
$\mathrm{~T}_{3}$ Langadu, Rangamati & 60 & & $7-10$
\end{tabular}

Table 2 Water quality parameters in three different creeks during experiments

\begin{tabular}{|c|c|c|c|c|c|c|c|c|}
\hline \multirow{2}{*}{ Treatments } & \multicolumn{8}{|l|}{ Parameters } \\
\hline & Air temp $\left({ }^{\circ} \mathrm{C}\right)$ & $\begin{array}{l}\text { Water temp } \\
\left({ }^{0} \mathrm{C}\right)\end{array}$ & $\mathrm{pH}$ & $\mathrm{CO}_{2}(\mathrm{mg} / \mathrm{l})$ & $\begin{array}{l}\text { Total alkalinity } \\
(\mathrm{mg} / \mathrm{l})\end{array}$ & $\begin{array}{l}\text { Total hardness } \\
(\mathrm{mg} / \mathrm{l})\end{array}$ & $\begin{array}{l}\text { Transparency } \\
(\mathrm{m})\end{array}$ & $\mathrm{DO}(\mathrm{mg} / \mathrm{l})$ \\
\hline Range & $21.46-29.06$ & $22.98-31.5$ & $6.85-7.45$ & $2.24-5.12$ & $36.14-63.2$ & $32.1-52.3$ & $1.22-2.26$ & $4.99-7.25$ \\
\hline $\mathrm{T}_{1}$ & & & & & & & & \\
\hline Mean & $26.26 \pm 3.8 \mathrm{a}$ & $27.24 \pm 4.26 \mathrm{a}$ & $7.3 \pm 0.45 \mathrm{a}$ & $3.52 \pm 1.6 \mathrm{a}$ & $52.32 \pm 3.51 \mathrm{a}$ & $42.05 \pm 4.22 \mathrm{a}$ & $1.35 \pm 0.35 \mathrm{a}$ & $6.12 \pm 1.13 \mathrm{a}$ \\
\hline Range & $25.68-31.02$ & $19.56-32.5$ & $6.36-8.24$ & $2.69-6.35$ & $41.2-70.5$ & $45.1-65.3$ & $1.25-2.44$ & $4.36-6.93$ \\
\hline $\mathrm{T}_{2}$ & & & & & & & & \\
\hline Mean & $28.35 \pm 2.67 \mathrm{a}$ & $26.03 \pm 6.47 \mathrm{a}$ & $7.3 \pm 0.94 \mathrm{a}$ & $4.02 \pm 1.33 \mathrm{a}$ & $70.3 \pm 0.2 b$ & $60.5 \pm 4.8 b$ & $1.82 \pm 1.19 \mathrm{a}$ & $6.27 \pm 0.66 \mathrm{a}$ \\
\hline Range & $25.35-32.51$ & $19.22-32.24$ & $6.2-8.20$ & $3.33-6.33$ & $59.3-72.1$ & $59.9-72.5$ & $0.54-2.50$ & $5.36-6.84$ \\
\hline Mean & $28.93 \pm 3.58 \mathrm{a}$ & $25.73 \pm 6.51 \mathrm{a}$ & $7.2 \pm 1.00 \mathrm{a}$ & $4.83 \pm 1.50 \mathrm{a}$ & $65.7 \pm 6.4 \mathrm{c}$ & $66.2 \pm 6.3 \mathrm{c}$ & $1.52 \pm 0.98 \mathrm{a}$ & $6.10 \pm 0.74 \mathrm{a}$ \\
\hline
\end{tabular}


Table 3 Growth performance of craps under polyculture management after 300 days of culture in three different creeks

\begin{tabular}{|c|c|c|c|c|c|c|c|c|c|c|c|}
\hline \multirow{2}{*}{ Treatments } & \multirow{2}{*}{$\begin{array}{l}\text { Stocking } \\
\text { density }\end{array}$} & \multirow{2}{*}{$\begin{array}{l}\text { Creek } \\
\text { size } \\
\text { (ha) }\end{array}$} & \multirow{2}{*}{$\begin{array}{l}\text { Carp } \\
\text { species }\end{array}$} & \multicolumn{2}{|l|}{ Initial } & \multicolumn{2}{|c|}{ After 300 days } & \multirow{2}{*}{ Weight gain (g) } & \multirow{2}{*}{$\begin{array}{l}\text { Survival } \\
\text { rate }(\%)\end{array}$} & \multirow{2}{*}{ SGR (\%) } & \multirow{2}{*}{ FCR } \\
\hline & & & & $\begin{array}{l}\text { Length } \\
\text { (cm) }\end{array}$ & Weight (g) & Length (cm) & Weight (g) & & & & \\
\hline \multirow{3}{*}{$\mathrm{T}_{1}$ Sadar } & \multirow{3}{*}{$80 / \mathrm{dec}$} & \multirow{3}{*}{0.1} & Rui & $6.3 c \pm 0.66$ & $14.60 \pm 1.51$ & $32.90 \mathrm{~b} \pm 1.20$ & $545.00 \pm 15.09$ & $530.40 \pm 15.09$ & 42 & $1.20 \pm .03$ & 1.53 \\
\hline & & & Catla & $7.26 \pm 0.40$ & $42.20 \mathrm{a} \pm 3.39$ & $33.70 \pm 2.31$ & $616.40 \pm 154.23$ & $574.20 \pm 154.85$ & 42 & $0.89 \pm .04$ & 1.38 \\
\hline & & & Mrigal & $8.00 \pm 1.25$ & $21.60 \pm 1.90$ & $33.00 \mathrm{a} \pm 1.15$ & $515.20 \pm 111.57$ & $493.60 \pm 112.36$ & 40 & $1.05 \pm .05$ & 1.56 \\
\hline \multirow{3}{*}{$\begin{array}{l}\mathrm{T}_{2} \\
\text { Naniarchar }\end{array}$} & \multirow{3}{*}{$70 / \mathrm{dec}$} & \multirow{3}{*}{0.1} & Rui & $7.07 \mathrm{~b} \pm 0.78$ & $14.50 \pm 1.08$ & $31.70 \mathrm{c} \pm 1.25$ & $553.20 \pm 92.76$ & $538.70 \pm 92.46$ & 47 & $1.20 \pm .04 \mathrm{a}$ & 1.81 \\
\hline & & & Catla & $7.54 \pm 0.68$ & $39.00 \mathrm{~b} \pm 2.26$ & $33.40 \pm 2.50$ & $630.60 \pm 124.50$ & $591.60 \pm 124.97$ & 45 & $0.92 \pm .06 \mathrm{~b}$ & 1.53 \\
\hline & & & Mrigal & $8.50 \pm 1.08$ & $22.80 \pm 1.10$ & $31.60 \mathrm{c} \pm 1.43$ & $528.80 \pm 88.41$ & $506.00 \pm 88.93$ & 44 & $1.04 \pm .07 \mathrm{c}$ & 1.49 \\
\hline \multirow{3}{*}{$\mathrm{T}_{3}$ Longodu } & \multirow{3}{*}{$60 / \mathrm{dec}$} & \multirow{3}{*}{0.1} & Rui & $8.40 \mathrm{a} \pm 1.17$ & $14.70 \pm 0.95$ & $33.50 \mathrm{a} \pm 1.35$ & $587.10 \pm 153.30$ & $572.40 \pm 153.90$ & 52 & $1.22 \pm .03 \mathrm{a}$ & 1.54 \\
\hline & & & Catla & $8.00 \pm 0.82$ & $38.80 \mathrm{c} \pm 1.93$ & $34.80 \pm 2.94$ & $661.30 \pm 292.93$ & $622.50 \pm 293.50$ & 51 & $0.94 \pm .08 \mathrm{~b}$ & 1.75 \\
\hline & & & Mrigal & $7.90 \pm 0.88$ & $22.10 \pm 2.77$ & $32.70 b \pm 0.67$ & $554.60 \pm 117.54$ & $532.50 \pm 118.32$ & 54 & $1.07 \pm .07 \mathrm{c}$ & 1.81 \\
\hline
\end{tabular}

Table 4 Average survival, gross production, net production and production of carp fish under polyculture management in three different creeks

\begin{tabular}{|c|c|c|c|c|c|c|c|}
\hline Treatments & Carp species & $\begin{array}{l}\text { Survival } \\
(\%)\end{array}$ & $\begin{array}{l}\text { Gross } \\
\text { production }\end{array}$ & $\begin{array}{l}\text { Net } \\
\text { production }\end{array}$ & $\begin{array}{l}\text { Production of fish } \\
\text { (No/0.1ha) }\end{array}$ & $\begin{array}{l}\text { Total production } \\
\text { (kg/0.1ha/10 } \\
\text { months) }\end{array}$ & $\begin{array}{l}\text { Total production } \\
\text { (kg/ha/10 months) }\end{array}$ \\
\hline \multirow{3}{*}{$\mathrm{T}_{1}$} & Rui & 42 & 171 & 161 & 315 & \multirow{3}{*}{468} & \multirow{3}{*}{4623} \\
\hline & Catla & 42 & 194 & 163 & 315 & & \\
\hline & Mrigal & 40 & 103 & 93 & 200 & & \\
\hline \multirow{3}{*}{$\mathrm{T}_{2}$} & Rui & 47 & 160 & 151 & 292 & \multirow{3}{*}{452} & \multirow{3}{*}{4465} \\
\hline & Catla & 45 & 176 & 152 & 280 & & \\
\hline & Mrigal & 44 & 116 & 105 & 220 & & \\
\hline \multirow{3}{*}{$\mathrm{T}_{3}$} & Rui & 52 & 190 & 181 & 325 & \multirow{3}{*}{470} & \multirow{3}{*}{4643} \\
\hline & Catla & 51 & 168 & 149 & 255 & & \\
\hline & Mrigal & 54 & 112 & 104 & 202 & & \\
\hline
\end{tabular}

Table 5 Comparison of economics of three different creeks calculated on the basis of 0.1 hectare creek

\begin{tabular}{|c|c|c|c|c|c|c|}
\hline Items & & Quantity & Price rate $(\mathrm{BDT})^{*}$ & $\mathbf{T 1}$ & $\mathbf{T} 2$ & T3 \\
\hline \multirow[t]{6}{*}{ A. Cost } & {$[(\mathrm{i})+(\mathrm{ii})+(\mathrm{iii})]$} & - & - & 67163 & 65203 & 63243 \\
\hline & Fixed cost & - & - & - & - & - \\
\hline & Land rent & - & 25000 ha-1,yr ${ }^{-1}$ & 2110 & 2110 & 2110 \\
\hline & Rotenone & $1.25 \mathrm{~kg}$ & $240 \mathrm{~kg}^{-1}$ & 300 & 300 & 300 \\
\hline & Lime & $25 \mathrm{~kg}$ & $30 \mathrm{~kg}^{-1}$ & 750 & 750 & 750 \\
\hline & Urea & $3 \mathrm{~kg}$ & $50 \mathrm{~kg}^{-1}$ & 150 & 150 & 150 \\
\hline \multirow[t]{6}{*}{ A (i): } & TSP & $10 \mathrm{~kg}$ & $30 \mathrm{~kg}^{-1}$ & 300 & 300 & 300 \\
\hline & Compost & $100 \mathrm{~kg}$ & $5 \mathrm{~kg}^{-1}$ & 500 & 500 & 500 \\
\hline & Rui & 750 no. & 7 fry $^{-1}$ & 5250 & 4375 & 3500 \\
\hline & Catla & 750 no. & 7 fry $^{-1}$ & 5250 & 4375 & 4375 \\
\hline & Mrigal & 500 no. & 7 fry $^{-1}$ & 3500 & 3500 & 2625 \\
\hline & Sub total & - & - & 18110 & 16360 & 14610 \\
\hline
\end{tabular}




\begin{tabular}{|c|c|c|c|c|c|c|}
\hline \multirow{5}{*}{ A(ii): } & Variable cost & - & - & - & \multicolumn{2}{|l|}{ - } \\
\hline & Feed & $800 \mathrm{~kg}$ & $30 \mathrm{~kg}^{-1}$ & 24000 & 24000 & 24000 \\
\hline & Labour & - & $300 \mathrm{Tk}$ day $^{-1}, 40$ days & 12000 & 12000 & 12000 \\
\hline & Other & - & - & 5000 & 5000 & 5000 \\
\hline & Sub total & - & - & 41000 & 41000 & 41000 \\
\hline $\begin{array}{l}\text { Total fixed and } \\
\text { variable costs } \\
{[\mathrm{A}(\mathrm{i})+\mathrm{A}(\mathrm{ii})]}\end{array}$ & - & - & & 59110 & 57360 & 55610 \\
\hline A(iii): & $\begin{array}{l}\text { Bank interest on cost } \\
\text { for } 300 \text { days }\end{array}$ & & $12 \%$ yearly & 8053 & 7843 & 7633 \\
\hline & B(i): Carp sale price & - & - & - & - & \\
\hline B Benefit [B(i)] & Rui & - & 200,200 and $200 \mathrm{~kg}^{-1}$ & 34200 & 32000 & 38000 \\
\hline B. Bentent [B(I)] & Catla & - & 180,180 and $180 \mathrm{~kg}^{-1}$ & 34920 & 31680 & 30240 \\
\hline & Mrigal & - & 170,170 , and $170 \mathrm{~kg}^{-1}$ & 17510 & 19720 & 19040 \\
\hline C. Net profit (B- $A$ & & & & 86630 & 83400 & 87280 \\
\hline D. Benefit cost ra & $\mathrm{BCR}(\mathrm{B} \div \mathrm{A})$ & & & 1.28 & 1.27 & 1.38 \\
\hline
\end{tabular}

*BDT, Bangladesh taka.

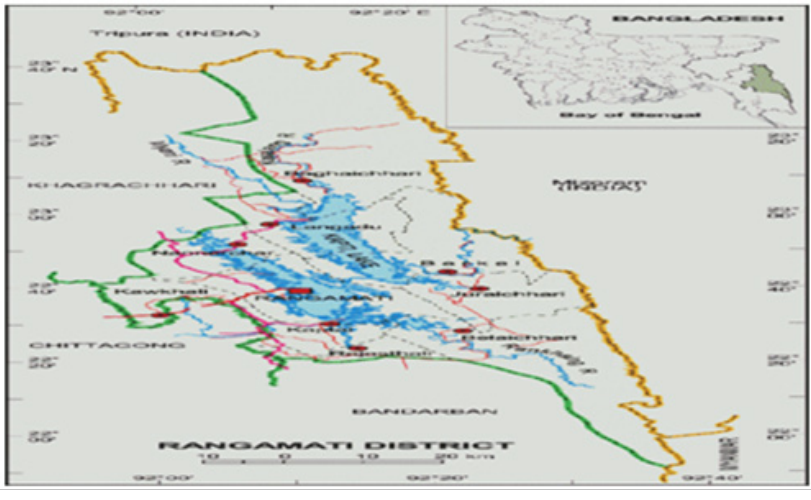

Figure I Map showing the study sites of Sadar , Langadu, Naniarchar Upazilla of Rangamati hill tracts of Bangladesh.

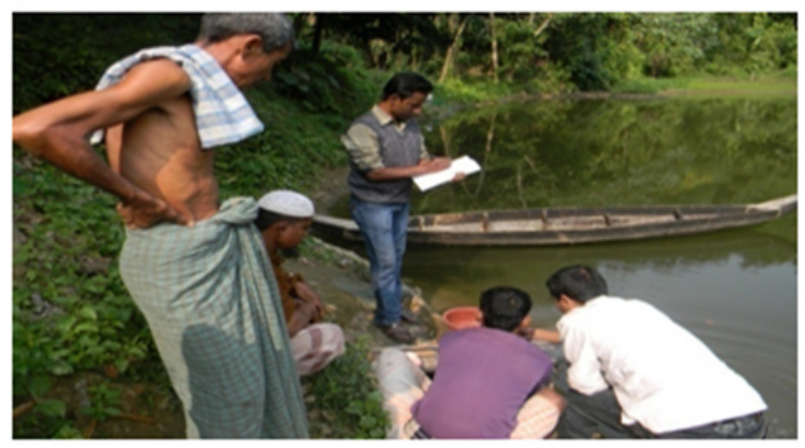

Figure 2 Growth performance of fishes.

\section{Conclusion}

In conclusion; it can be corroborated that on the basis of growth performance and economic return; 60fish/decimal exhibited the highest performance to all stocking densities. Therefore; stocking density of $60 \mathrm{fish} /$ decimal recommended for the successful polyculture in hilly creeks. This study has implications of sustainable and costeffective polyculture practices in hilly creeks.

\section{Acknowledgements}

This research work was fund by Fish production, conservation and strengthening Management at Kaptai Lake (component-C Part) Project (code no. 05-4405-5470) under the Ministry of Fisheries and Livestock (MOFL) of the government of Bangladesh. The authors would like to extend their cordial appreciation to principle investigator, co- investigators, office employees and farmers for overall co-ordination of the project.

\section{Conflict of interest}

The author declares no conflict of interest

\section{References}

1. Fish week Compendium, Department of Fisheries. Ministry of Fisheries and Livestock. Bangladesh: DoF; 2012.

2. Alamgir M, SU Ahmed. Fish culture techniques in creeks in Kaptai Lake using pens. Extension Manual No. 33. Bangladesh Fisheries Research Institute. 2005. 16 p.

3. Bashar MA, Basak SS, Uddin KB, et al. Changing trends of physicochemical parameters in Kaptai lake of bangladesh. Research in Agriculture, Livestock and Fisheries. 2015;2(2):319-327.

4. Halver JE. Special methods in pond fish husbandry. Budapest: Akademiai Nyomd; 1984. 146 p. 
5. Bashar MA, Basak SS, Uddin KB, et al. Development of Indian major carp fry raising techniques in creeks of Kaptai Lake, Bangladesh. World J. Fish and Marine Sciences. 2014;6(6):532-536.

6. Alim MA, MA Wahab, A Milstein. Effect in increasing by $20 \%$ the stocking density of large scarps of basic "cash" carp-small fish polyculture of Bangladesh. Aqua Res. 2005;36:317-325.

7. Raihan A. To assess the effect of adding puti, Puntius sophore and Mokla, Amblyphyryngodon mola in carp polycultyure, M.S. thesis. Department of Management. Mymensingh, Bangladesh: Bangladesh Agriculture University; 2001. 76 p.

8. Islam S. Growth performance of carp in pond fertilized with animal manures, M. S. thesis, Department of Aquaculture. Mymensingh, 15 . Bangladesh: Bangladesh Agriculture University; 2009.

9. Milstein AM, Wahab A, Kabir MFH, et al. Effect if intervention in the column and/or pond bottom through species composition on polyculture of large carps and small indigenous species. Aquaculture. 2009;286(34):146-253.

10. Kohinoor AHM, Islam ML, Wahab MA, et al. Effect of mola (Amblypharyngodon mola Ham.) on the growth and production of carps in polyculture. Bangladesh J Fish Re. 1998;2(2):119-126.

11. Kadir A, RS Kunda A Milstein, MA Wahab. Effect of silver carp and small indigenous species on pond ecology and carp polyculture in Bangladesh Aquaculture. AGIRS. 2006;261:1065-1076.
12. Roy NC, Wahab MA, Khatoon H Thilsted SH. Economics of Carp-SIS polyculture in rural farmer's pond. Pakistan $J$ Biological Sciences. 2003;6(1):61-64.

13. Sagor MFH. Effect of different combinations of carps on pond ecology and fish production in carp-mola polyculture, MS thesis. Department of Aquaculture. Mymensingh: Bangladesh Agriculture University; 2008. 62 P.

4. Hossain HZ. Effect of inorganic fertilizers on growth, production, protein and lipid contents of carps in polyculture system, MS thesis, Department of Aquaculture. Mymensingh, Bangladesh: Bangladesh Agriculture University; 2008.

5. Modac JC. Comparative growth study of Rui (Lebeo rohita) under monoculture and Indian carps polyculture system, M. S. thesis, Department of Aquaculture. Mymensing, Bangladesh: Bangladesh Agriculture University; 2006.

6. Kohinur AHM. Development of culture technology of three small indigenous fish mola (Amblyphyryngodon mola), puti, (Puntius sophore) and Chela (Chela cachius) with notes on some aspects of their biology, Ph. D. thesis, Department of Management. Mymensingh, Bangladesh: Bangladesh Agriculture University; 2000. 